\title{
Issues and Challenges of Unregistered Franchise Business: A Malaysian Legal Perspective
}

\author{
HUA SIONG WONG \\ School of Law, College of Law, Government and International Studies UNIVERSITI UTARA MALAYSIA (UUM), \\ MALAYSIA. E-mail: wonghuasiong@yahoo.com
}

\begin{abstract}
The Malaysian Parliament had enacted the Franchise Act in 1998 and one of the main purposes of this Act is to monitor the registration and regulate franchise businesses in Malaysia to ensure that all the franchise businesses are following laws and regulation. Registration of franchisor (including registration of foreign franchisor) and franchisee has been stated in section 6 and 6B of the Franchise Act 1998. However, the Franchise Act 1998 is silent whether registration of a franchise business is mandatory. Meanwhile, the next issue is whether an unregistered franchise business established under a licensing or dealership agreement can register the franchise after the conclusion of the licensing agreement. The objective of this article is to look into the legal perspective of unregistered franchise business in Malaysia and suggest some proposals on how to overcome the legal issues of unregistered franchise business in Malaysia. This is qualitative study that involves a systematic study of philosophical and academic views through literatures. Therefore, this study is not an empirical study but rather a library study from various primary and secondary data sources. The study found that the Franchise Act 1998 may post a business risk to businesses intended to expand. As an innocuous venture agreement may end up becoming a franchise agreement, and an unregistered business owner may suddenly find himself at the short end of the stick, may be subject to the civil and criminal liabilities due to non-compliance of the Franchise Act 1998. As such, it is suggested that the Franchise Act 1998 should provide more monitoring and quality control over a potential franchise business before it is offered to protentional franchisees.
\end{abstract}

Keywords: Challenges; Legal Issues; Malaysia, Unregistered Franchise

JEL Classification: K29 


\section{Introduction}

The franchising industry has flowered over the years in Malaysia, especially in the food and beverage industry. Before the enactment of Franchise Act 1998 (hereinafter referred to as 'the FA $\left.1998^{\prime}\right)$, franchising in Malaysia was generally governed by contractual principles. Franchise Act 1998 was enacted by the Malaysian Parliament in 1998. This Act came into force on 8 October 1999 and has subsequently undergone a major amendment exercise in 2012 and a minor amendment in 2020. The purpose of the FA 1998 is to register, regulate and monitor franchises in Malaysia. If we look at other countries such as Australia and the United States of America, they had a franchising law much earlier than Malaysia. Legislation in Australia emerged during the 1970s and 1980s when the state levels and territories created their own Franchising Commissioners in order to collect levies in certain industries, while Malaysia enacted its Franchise Act in 1998, two decades after the introduction of franchising law in the United States of America. In United Kingdom, they chose not to have any specific legislation on franchising. Thus, it can be seen that Malaysia is quite slow in recognising and developing franchising law compared to other countries and may not have any mechanism to monitor the unregistered franchise business in the country. In any event, Malaysia took initiative to regulate law on franchising which required all the franchise businesses need to be registered in order for the government to monitor the franchise activities in Malaysia. Generally, registration system of franchise in Malaysia can be explained as follows:

Figure 1. Various registration stages in the Malaysian franchise system.

REGISTRATION SYSTEM OF FRANCHISE IN MALAYSIA

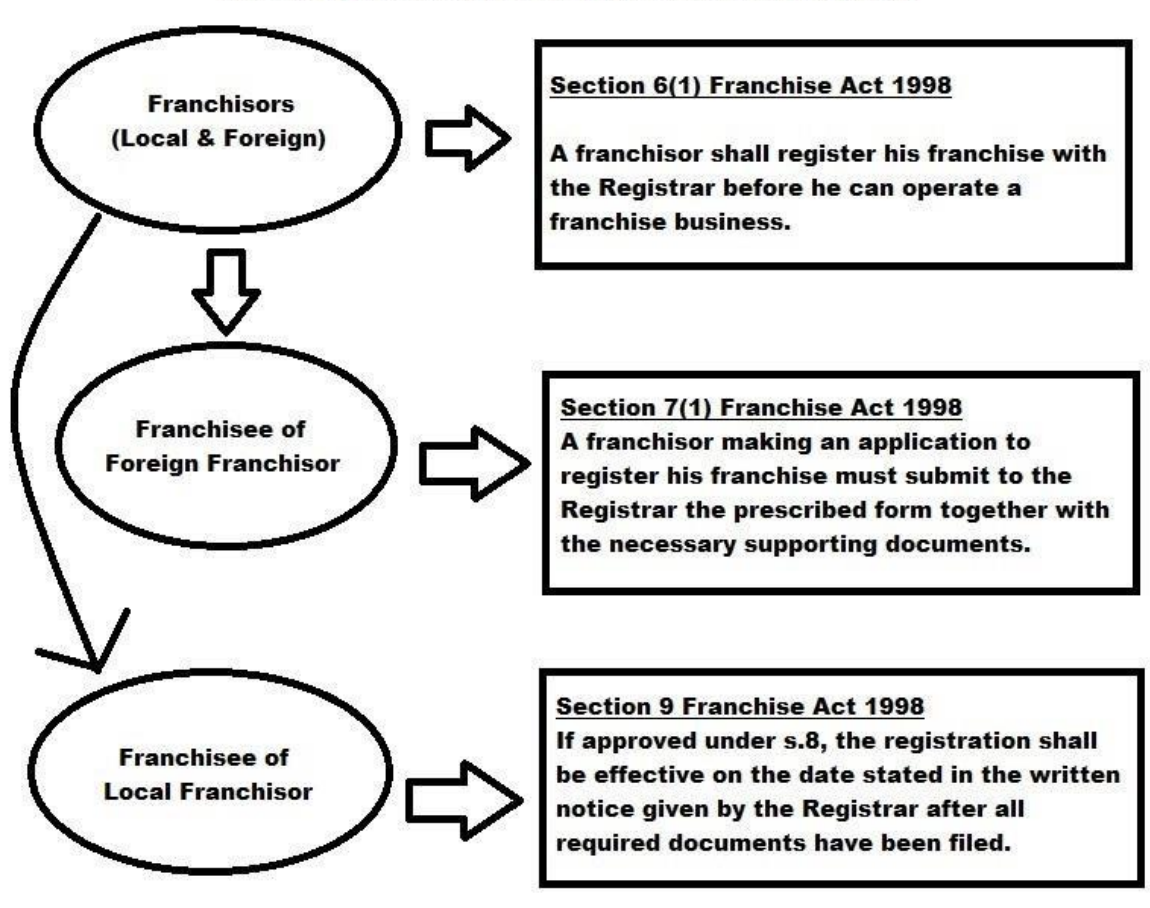

\section{Literature Review}

The term 'franchise' has been defined in section 4 of the FA 1998, namely franchise is an oral or written agreement between both franchisor and franchisee in which the franchisor grants the franchisee the right to use its trade mark or intellectual property and operate the franchisee's business according to the franchisor's franchise system which is determined by the franchisor. However, the franchisor will remain the right to administer and control the franchisee's business operations to make sure that the franchisee complies with the franchise system determined by the franchisor. In return, the franchisee needs to pay a fee, loyalty or other form of consideration to the franchisor. Unfortunately, we should not define a 'franchise' as 'as contract or an agreement. It is because under 
FA 1998, the term 'franchise' is not used to define or refer to a contract at all, but more to describe a form of a business model or a property right.

The Franchise Counsel of Australia (FCA, 2018) recommends that an industry-led proposal for universal registration of Australian franchise systems be supported by the Committee. In the view of the FCA, just as voluntary compliance with the Franchising Code of Conduct did not work and the Code was enforced in 1998 as a compulsory Business Code, voluntary registration of franchise systems was insufficient. Mandatory registration of franchise systems could provide franchisees with significant additional security, but not tip the balance too far or eliminate the significant duality of liability that a business joint venture can underpin where the franchisee enjoys all the advantages of net income and capital development. According to Natalya (2010), all franchise agreement, referred to as 'commercial concessions' in Russia, are required to register with the Russian patent and trademark office, namely Rospatent. The franchise agreement has no legal validity until it has been registered.

In United Kingdom, since there are no specific franchise laws, British Franchising Association (BFA) used its codes and ethics to regulates franchise system in the country. Although this BFA code subsequently applies to BFA member only but UK High Court changed its opinion overtime in Re Drivetime Recruitment Ltd Re DST Ltd., a case where winding up of a franchise whose franchisor was not a member of BFA, the court recognized the significance of BFA code while analyzing the behavior of franchisors in general. Besides the BFA code, there is an U.K. Competition Act of 1968 regulates all kinds of agreements in the country inclusive of franchise agreements.

Franchise sector in India is at a developing stage and they do not have specific regulations that regulate the franchise law in the country. Franchise agreements are therefore contractual and governed by various other statues and legislations which determine the type of relationship between the franchisor and franchisee. For instance, Indian Contract Act 1872, Monopolies and Restrictive Trade Practice Act 1969, Competition Act 2000, Transfer of Property Act 1882, Consumer Protection Act 1986, Intellectual Property Laws, Indian Taxation Act 1961 and Foreign Exchange Management Act 1999.

Unlike the typical situation in the United States, there is an additional overlay of government activity that exists under the franchise laws of some countries. It is not entirely true that nothing of this sort exists in the United States. Here, under some state laws, the regulators are given the authority to refuse to register a franchise organization if they conclude that the franchisor does not have sufficient net worth or its financial outlook is not stable (Byron E. Fox \& Bruce S. Schaeffer, 2005).

Franchising in Malaysia is still suffers from a lack of reliable information and under researched área (Mohd Ali, 1995). In Malaysia context, many franchisees were found facing the problem in managing their business and to some cases they have to be terminated due to poor performance and none registration of franchise business. If there is no specific law governing franchise business, unregistered franchise will become an social issue. This is because there will be many unregistered franchise in the market which may affect the consumer or franchisees' interest.

Thus, few problem statements and issues will be discussed in the research including the what are the requirements for registration of franchise business, what are the reasons for non-registration of franchise business including non-registrable 'franchise' business and what are the effects of failure to register the franchise business to both franchisor and franchisee.

\section{Methodology}

This is qualitative study that involves a systematic study of philosophical and academic views though literatures. Therefore, this study is not an empirical study but rather a library study from various primary data sources franchising agreement, cases, statutes and secondary data sources namely articles and journals from online database. This article employs a doctrinal analysis and secondary data were collected from academic journals and online databases. The sources of the data are taken from legislation, Code, guidelines and decided case on the concept of unregistered franchise business in 
Malaysia. Library research was conducted to gain information on the concept of unregistered franchise business based on the text books, journal articles and other relevant sources.

\subsection{Research Design}

The design of this study is socio-legal. Socio-legal studies exist because the law was established as a mechanism to manage the affairs and conflicts that arise in a social community. Thus, the law has a close relationship with society. Socio-legal research is a research method that brings together two major fields of research in the social sciences and the field of law. First, the technique of interpretation of statutes which consists of the literal rule, golden rule, mischief rule and purposive approach will be adopted. Here, the provisions relating to unregistered franchise under the Franchise Act 1998 will be analyzed. Second, the doctrine of judicial precedent will also be used in this research to analyze cases that are related to unregistered franchise.

\subsection{Research Scope}

The legal documents that will be the scope for this research is the Franchise Act 1998 and its regulations; Rules and Guidelines. The court cases that will be analysed in this study too.

\subsection{Types of Data}

This study will use primary data and secondary data. The primary data for this study are the statutes, regulations, rules and guidelines relating to unregistered franchise and decided cases involving unregistered franchise. Secondary data of this study comprises of books, legal documents, and articles from journals and online resources.

\subsection{Methods of Data Collection}

Methods of data collection for this study is library research. For library research, data will be collected from Sultanah Bahiyah Library Universiti Utara Malaysia, law library of International Islamic University Malaysia, Universiti Kebangsaan Malaysia and Universiti Malaya.

\subsection{Data Analysis}

Generally, the primary legal data and secondary data will be analysed using content analysis. Specifically, the provisions relating to unregistered franchise under the Franchise Act 1998 and relevant statutes, rules and guidelines will be analysed by using interpretation of statutes techniques. While, court cases that relate to unregistered franchise will be analysed by using the doctrine of judicial precedent.

\section{Results and findings}

\subsection{Requirement for registration}

As at first half year 2020, the total number of franchise businesses registered with the Registrar of Franchise ('ROF') in Malaysia is 646 companies, comprising 583 homegrown brands and 63 foreign brands (The Star, 2020). The Ministry of Entrepreneur and Cooperative Development ('MECD') is taking serious obervation to ensure all existing franchises to comply with the terms set by ROF. In order to monitor the franchise activities in Malaysia, it is mandatory for a franchisor to register a franchise as provided in section 6(1) of the FA 1998. This section has been amended by Franchise (Amendment) Act 2012 by inserting a new offence of the franchisor operating a 'franchise business' before registration. However, 'franchise business' is not defined by Franchise (Amendment) Act 2012. The Franchise (Forms and Fees) Regulations 1999 also did not define the term 'franchise business', but from the context of the forms, it is clear that the term 'franchise business' refers to the business that the franchisee will get from entering into a franchise contract. 
Meanwhile, the current section 6B(1) of the FA 1998 requires a franchisee of a local franchisor who has been granted a franchise from a local franchisor or local master franchisee to register the franchise with the Registrar of Franchise within fourteen (14) days from the date of signing of the franchise agreement. With the proposed amendment, it will be an offence for any franchisee who fails to do so.

The Malaysian Franchise (Amendment) Bill 2019 has been passed by the Dewan Rakyat (House of Representatives) on 3 December 2019 and The Bill received its Royal Assent on 20 February 2020 and published in the Gazette on 6 March 2020. The Bill seeks to amend the Franchise Act 1998 to be in line with the current developments of the franchise business in Malaysia. Under the new amendment, section 6(1) of the Franchise Act 1998 requires a foreign franchisor to register himself under sections 6 and 54(1) of the Franchise Act 1998 separately. It means there will be double registration of franchise by foreign franchisor. However, it is unclear if the applications can be done simultaneously or consecutively.

It is important to note that a franchisor is obliged to make an application to register one franchise business with the Registrar of Companies prior to the operation of a franchise business to grant a prospective franchisee the right to operate a franchise failing which whatever franchise contract or agreement entered between the parties will deem to be illegal, ineffective and void. This can be seen in the case of Dr Premananthan a/I Vasuthevan v Permai Polyclinics Sdn Bhd, the High Court held that, if a franchise is not duly registered under Section 6 of the FA 1998, any franchise contract or agreement made under such circumstances will be in contravention of the said provision and thus illegal, ineffective and void.

From pre-contract disclosure requirements, registration and submission of key contractual documents, express provisions on parties' rights and obligations, renewal \& termination, even upholding 'restraint of trade' clauses (during and post franchise term) which are disallowed under the Contracts Act, operation of a franchise is extensively regulated. As stated by the High Court in Noraimi bt Alias v Rangkaian Hotel Seri Malaysia, "the Franchise Agreement takes a dimension beyond the simple private business relationship between the contracting parties to one that includes the interests of the consumer and good business practices". A franchisor must register the franchise with the Registrar of Franchises before he can operate the franchise business or make an offer to sell the franchise to any person. There is also an onerous list of disclosure documents to be submitted by the franchisor as part of the application for registration. The importance of the registration of franchise is explained in the case of Noraimi Alias (supra):

"A quick perusal of the Act shows the regulation of franchise is through a system of registration of franchises. The importance of registration is reflected in the imposition of penalties. Unless the person, class of persons, business or industry is exempted from all or any of the provisions of the Act, including the requirement of registration, the failure to register before offering the franchise for sale is an offence. [Emphasis Added]"

In the case of Tea Delights (M) Sdn. Bhd. $v$ Lim Seng Kiat \& Ors, the court referred to the case SP Multitech Intelligent Homes Sdn. Bhd. $v$ Home Sdn. Bhd. and came to the same reasoning that if a franchisor fails to register a franchise agreement the agreement is tainted with illegality. In fact, the court emphasised that registration should be the first step before a franchisor offers to sell the franchise to the franchisee. As a result, since the agreement is deemed unlawful, the defendant in this case is liable to restitute the money paid. Thus, we could infer that majority of cases conclude that if a business falls within the definition of a 'franchise', registration is mandatory. Failure to register a franchise would make an agreement illegal and void.

Further thereto, section 6A of the FA 1998 has also provided that registration of a franchisee of a foreign franchisor. A Franchisee who has been granted the right to operate a franchise of a foreign franchisor must register the said franchise with the Registrar prior to the commencement of the franchise business. If we refer to a decided case in Malaysia, namely in the case of Dr HK Fong Brainbuilder Pte Ltd v Sg-Maths Sdn Bhd \& Ors, the High Court took the view that all franchises, both local and foreign, must be registered with the Registrar. Although the plaintiff in the said case 
contended that the registration of franchises under Section 6 of the FA 1998 was only applicable to local franchisors, the High Court reasoned that, if a foreign franchisor is not required to register its franchise with the Registrar, the foreign franchisor may be able to avoid compliance with the mandatory provisions in the Franchise Act 1998 for the protection of franchisees. This comes as an addition to the requirements under Section 54 of the Franchise Act 1998, which stipulates that a foreign person intending to sell a franchise in Malaysia or to any Malaysian citizen is required to submit an application to the Registrar.

Prior to making an application to register the franchise, the franchisor must first ensure that the trademark or service mark relevant to the franchise is duly registered in accordance with the Trade Marks Act 1976, if the intellectual property is registrable. In the case of a foreign franchisor, the foreign franchisor must ensure that the trademark or service mark relevant to the foreign franchise is duly registered in its country of origin. Upon the satisfaction of the registration of the relevant trademark or service mark, an application to register the franchise may be made to the Registrar. The application is to be submitted by the franchisor to the Registrar, and must be accompanied by the following documents and information including but not limited to a copy or sample of the franchise agreement, the operation and training manuals of the franchise, a copy of the latest audited accounts, financial statements and reports, if any, of the auditors and directors of the applicant; and such other additional information or documents as may be required by the Registrar for the purpose of determining the application. In addition to the submission of the above, all of which are as prescribed by the Franchise Act 1998, the following documents are also required to be submitted by the applicant, namely registration application form; Certificate of Incorporation; Forms 24 and 49; the franchisor's organizational chart with the names and position of key personnel; and the franchisor's business brochures.

\subsection{Reasons for non-registration}

Various reasons exist for why a business is not registered as a franchise. Firstly, a person may decide not to register his franchise by avoiding the use of the word 'franchise' and adopts other terms such as 'licensing' or 'dealership'. Contrary to franchising law in Malaysia, apart from registration of a trade mark user, licensing does not require registration as the licensing agreement is often regulated by the licensing agreement. The FA 1998 does not specifically mention or define 'dealer' or dealership. Furthermore, most of the cases relating to franchise disputes only explained that a business is deemed to be a franchise provided that it satisfies the definition of 'franchise' in section 4 of the FA 1998. However, according to clause 5(2)(c) of the Australia Franchising Code of Conduct, motor vehicle dealership is recognised as a franchise agreement. In the United States, the Federal Automobile Dealers' Franchise Act recognised on automobile dealership relating to franchise.

Secondly, a business owner does not know that he has to register his franchise due to ignorance of the law. Thirdly, the business cannot be registered as a franchise because the four conditions for a franchise in section 4 are not fulfilled. This could amount to non-registrable business, for example partnership and co-ownership, licensing and dealership. Section 29(3) of the FA 1998 states that the relationship of the franchisee with the franchisor shall not at anytime be regarded as a partnership, service contract or agency. Thus, this section implies that a partnership agreement registered under the Partnership Act 1961 does not become a franchise. If in such case, a joint venture or co-owned business between a 'franchisor' and a 'franchisee' in the form of a company registered under the Companies Act 2016 is arguably not a franchise business too.

Finally, despite fulfilling the four conditions in section 4, an application to register a franchise may be rejected by the Registrar under section 8 of the Franchise Act 1998. It appears that apart from the four conditions in section 4, the Registrar in practice imposes other conditions, which can be found in the Guide Book for Registration. Examples of these are the franchisor's business has been in operation for at least three years with three years' of audited account, and has a premises or prototype outlet for the franchise business for at least six months. 


\subsection{Non-registrable business}

If a business does not fulfill the definition of 'franchise' under section 4 of the FA 1998, it is arguable that the said business cannot be registered as a franchise business and thus the owner does not require to seek for registration. However, most of the times a business may not satisfy the four conditions in one point of time, but subsequently satisfy these four conditions inadvertently. As a result, the agreement made may be rendered void for failure to register the business. There are few examples of non-registrable business.

\subsubsection{Partnership}

One example of non-registrable business is a partnership. Under section 3(1) of the Malaysia Partnership Act 1961, it defines partnership as the relation which subsists between persons carrying on business in common with a view of profit. Although subsection 29(3) of the Franchise Act 1998 states that the franchisee shall operate the business separately from the franchisor, and the relationship of the franchisee with the franchisor shall not at anytime be regarded as a partnership, service contract or agency, but this section doest not define that a partnership cannot be a franchise. The question arises of whether it is possible to supersede subsection 29(3) of the Franchise Act 1998 seince the agreement was not intended as a franchise agreement? This situation would not be a problem to cases where the parties are constructing franchise agrements as the parties would not perceive their agreements as partnership agreements.

\subsubsection{Licensing}

The terms 'franchising' and 'licensing' are often caused consfusion as both terms have a similar concept. The term 'licence' is not defined in legislation. As there is no one specific legislation which governs or prescribes how the licensor-licensee relationship should be, the licensing model is largely governed by the actual contract freely negotiated between licensor and licensee. Contrary to franchising law in Malaysia, licensing does not require registration as it is often regulated by the licensing agreement itself. As discussed earlier in the case of $\mathrm{Dr} H \mathrm{~K}$ Fong Brainbuilder Pte Ltd $v \mathrm{Sg}$ Maths Sdn Bhd \& Ors, even though the Master License Agreement in question was not titled a "franchise" nor did it use the word "franchise", the High Court held that it is not bound by the label or description given by the parties to the agreement. The Court went on to conclude that a perusal of the Master License Agreement clearly showed that it fulfilled all four mandatory elements constituting a "franchise" and thus, the Franchise Act applied to the "Master License Agreement". However, in the Court of Appeal, the Malaysian Court of Appeal affirmed that an unregistered franchise agreement is void for illegality. This case stressed that franchise registration requirements apply to the peril of foreign and local franchisors alike.

In the case of Munafya Sdn Bhd v Profquaz Sdn Bhd, the High Court held that a licence agreement can qualify as a franchise agreement and a licensor cannot offer to sell or provide a franchise until his franchise is registered in Malaysia.

\subsubsection{Dealership}

Another similar concept related to franchise is dealership. Definition of dealer would be subject to the nature of business. In Australia, franchising law recognised the position of dealership in franchising law. For example, according to clause 5(2)(c) of the Australian Franchising Code of Conduct, motor vehicle dealership is recognised as a franchise agreement. In the United States, a specific legislation on automobile dealership relating to franchise known as the Federal Automobile Dealers' Franchise Act, at 15 U.S.C. $\S 1221$ (US legislation) was enacted to deal with dealership issues relating to franchising law.

Thus, although it does not mention all types of dealer, it seems that Australia and the United States clearly recognise automobile or motor vehicle dealer, as part of franchise where dealer is clearly stated 
and defined in their respective legislation to avoid ambiguity. Compare with Malaysian Franchise Act 1998, this Act does not have a specific position of dealership with regards to francshing law.

\subsection{Effect of failure to register}

Failure of the franchisor to register the franchise is an offence under subsection 6(2) of the FA 1998. Subsection 39(2) of the FA 1998 provides the general penalties for non-compliance of the FA 1998. It is arguable that in order to avoid non-compliance with the requirements of the FA 1998, it should be followed with a criminal conviction.

In the case of the SP Multitech Intelligent Homes Sdn. Bhd. v Home Sdn. Bhd. (supra), a franchise agreement was signed prior to the approval of the registration by the Registrar. The High Court decided that since the defendant had contravened section 6 of the Franchise Act, the Franchise Agreement is tainted with illegality and thus void ab initio under the paragraph 2(g) of the Contracts Act 1950. However, the court allowed for restitution of payment made by the defendant under section 66 of the Contracts Act 1950 since the said Franchise Agreement is void. Contrary to the approach taken in this case, the High Court in Noraimi bt Alias v Rangkaian Hotel Seri Malaysia (supra) held that a Franchise Agreement entered into prior to the coming into force of the Act and not registered under section 61 of the FA 1998, may still be enforceable and the rights provided in the Franchise Act may still be available to the franchisee.

On the other hand, the High Court of Australia in the case Yango Pastoral Co Pty Ltd v. First Chicago Australia $L t d$ is instructive in the manners in which illegality may render a contract unenforceable. Thus, non-registration of the franchise business prior to contracting the franchise agreement may cause the contract although lawful according to its own terms, but may be performed in a manner which the statute prohibits.

Thus, it is arguable based on the most of the decided cases, if a business falls within the definition of a 'franchise', registration is mandatory failing which may render the franchise agreement entered becomes illegal and void.

\subsection{Case study}

\subsubsection{Case Study 1:}

If a local businessman, Shan, intends to start selling franchises for his restaurant in the future but has yet to get his restaurant in order (i.e., competent staff hired and trained or accounting systems in place, etc) - is Shan considered to be "operating a franchise" and does he need to register his "franchise"?

In such situation, Franchise Act 1998 does not require him to register his franchise because section 4 defines a "franchise" is to mean an agreement between two parties where one party grants the other the right to operate a business according to a system and rights to use the Intellectual Property of the franchisor. The franchisor possesses the right to administer continuous control during the term over the franchisee's business operations to ensure it is carried out according to the predetermined system. Thus, Shan in this case is merely running his own business and there is no franchisor or franchisee in his business. Only when Shan decides that his business is ready to be franchised and begins discussions with potential investors who are interested to take up a franchise or become a franchisee, then that will be considered "an offer to sell a franchise" and Shan will be caught by the Act. Therefore, prior to that discussion, Shan should register his business with the Franchise Registry.

\subsubsection{Case Study 2:}

Minnie is a Malaysian who has bought a franchise from an Aussie ice cream parlour. She is the Master Franchisee for the Malaysian market and her franchise agreement allows her to sell franchises to other interested parties in Malaysia. However Minnie is not keen to explore that option as yet and 
prefers to operate her own ice cream parlours under the franchise. Is Minnie considered to be "operating a franchise" and does she need to register her "franchise"?

Before we examine whether Minnie is required to register her franchise, we need to determine whether is there a franchise agreement between two parties? The answer to this question is in affirmative. Then does Minnie intend to opérate the franchise in Malaysia? The answer would be yes too. Although it appears as if Minnie has to register her franchise as she "is operating a franchise" that is not the case. Remember - she is operating a franchise as a "franchisee" and not as a "franchisor".

Prior to the amendment of the Franchise Act 1998 in 2012 and 2020, only franchisors are required to register their franchises and in this case Minnie is not required to register her franchise because Minnie was considered a "franchisee" and not a "franchisor", she would not need to register his franchise. She will only require to register her franchise business only when she becomes a "franchisor" by virtue of selling sub-franchises to other franchisees, does she fall within the Act and registration becomes compulsory.

However with the changes introduced by the Ministry, the amended Act requires all "franchisees" to register their business with the Registry regardless of whether they have been granted a franchise from a local or foreign franchise. Thus, Minnie will therefore be caught within the amended Act and will need to register her franchise before commencing her business.

\section{Conclusion}

The Franchise Act 1998 is valuable Act to regulate and develop the franchise industry in Malaysia to greater heights. It provides for monitoring and quality control over a potential franchise business before it is offered to potential franchisees. Moreover, certain rights and protections to both franchisors and franchisees are offered in the Franchise Act 1998.

However, the registration of a franchise in Malaysia requires strict compliance with the various requirements set out in the Act. The process may appear to be straightforward, however, all contracting parties must be diligent in the preparation of the Registration Documents to register the intended franchise. This is pertinent in order to avoid setbacks or delays in the registration and/or operation of their intended franchise.

With the wave of globalization having hit business structure of major companies around the globe, franchising seems to be an attractive and lucrative option for foreign brands to expand globally. The future of franchising is bright and clear; however, it is recommended to consult a lawyer before entering into franchise agreements due to dissimilarities of laws in countries. On the other hand, the Franchise Act may post a business risk to business intended to expand. An innocuous venture agreement may end up becoming a franchise agreement and an unregistered business owner may suddenly find itself at the short end of the stick, and may be subject to criminal and civil liabilities for non-compliance of the Franchise Act 1998.

\section{Referencias}

1. Australian Franchising Code of Conduct.

2. Byron E. Fox \& Bruce S. Schaeffer, Fracnshie Regulation and Damanges $\$ 2.02$ (2005). (discussing various state laws and procedures by which a state examiner may determine that the franchisor has inadequate funding, and therefore require the franchisor to comply with bonding or escrow procedures.)

3. Donovan \& Ho (2018). Franchising vs Licensing: What's the Difference? $<$ https://dnh.com.my/franchising-vs-licensing-whats-the-difference/>. Accessed on 28 October 2020.

4. Dr HK Fong Brainbuilder Pte Ltd v Sg-Maths Sdn Bhd \& Ors [2018] MLU 682, [2021] 1 CL 155.

5. Dr Premananthan a/I Vasuthevan v Permai Polyclinics Sdn Bhd. [2015] MLcon 127 
6. Federal Automobile Dealers' Franchise Act

7. Franchise Act 1998 (Act 590)

8. Franchise (Amendment) Act 2012 (Act A1442)

9. George SK and Smriti Ganotra (2018). 'Worldwide: A Global Analysis Of Franchise Agreement'. <https://www.mondaq.com/franchising/685978/a-global-analysis-of-franchise-agreement>. Accessed on 28 October 2020.

10. Michael T. Schaper and Jenny Buchan (2014). 'Franchising in Australia: A History', 12 Int'l J Franchising L3.

11. Ministry mulls reducing franchise business start-up capital to only RM50,000, The Star, 3 September 2020. < https://www.thestar.com.my/business/business-news/2020/09/03/ministrymulls-reducing-franchise-business-start-up-capital-to-only-rm50000>. Accessed on 28 October 2020.

12. Mohd Ali, A. (1995). The franchise development programme in Malaysia: A public/private sectors synergy to promote Bumiputera participation in franchising. Unpublished, Malaysian International Franchise Malaysia Conference \& Exhibition, Kuala Lumpur.

13. Munafya Sdn Bhd v Profquaz Sdn Bhd, GUAMAN SIVIL NO: 22NCVC-10-01/2012.

14. Natalya Babenkova (2010). 'Unregistered agreements: dangers of deferral for franchisors', $<$ https://www.internationallawoffice.com/Newsletters/Franchising/Russia/Noerr/Unregisteredagreements-dangers-of-deferral-for-franchisors $>$. Accessed on 28 October 2020.

15. Noraimi bt Alias v Rangkaian Hotel Seri Malaysia [2009] 9 ML 475

16. Re Drivetime Recruitment Ltd Re DST Ltd [2004] ALL ER (D) 180 (Jul).

17. SP Multitech Intelligent Homes Sdn. Bhd. v Home Sdn. Bhd. [2010] MLJU 1845

18. Supplementary Submission by the Franchise Council of Australia to the Parliamentary Joint Committee on Corporations and Financial Services' Inquiry into the operation and effectiveness of the Franchising Code of Conduct (September 2018). Franchise Council of Australia.

19. Trade Marks Act 1976

20. Tea Delights (M) Sdn. Bhd. v Lim Seng Kiat \& Ors. [2015] 1 LNS 936

21. Yango Pastoral Co Pty Ltd v. First Chicago Australia Ltd

22. Zahira Binti Mohd. Ishan (2006). 'The Multidimensional Nature of Franchising', [2006] 1 ML Ixxxv.

23. The references will be numbered: Calibri 11 , space after $3 \mathrm{pt}$; single spacing.

24.García, M. D. L. N. L., \& Requena, J. P. R. (2019). Different methodologies and uses of the Hurst exponent in econophysics. Studies in Applied Economics, 1(13), 37-2. 